\title{
Correction to: Pharmacological Approaches to Managing Violence and Aggression in Prison Populations: Clinical and Ethical Issues
}

\author{
Michael Weightman ${ }^{1,2}\left(\mathbb{D} \cdot\right.$ Ranjit Kini $^{1,3} \cdot$ Robert Parker $^{1,2,4} \cdot$ Mrigendra Das $^{1,2,3}$ D
}

Published online: 26 February 2022

(c) The Author(s) 2022

\section{Correction to: Drugs (2020) 80:1635-1647 https://doi.org/10.1007/s40265-020-01372-2}

The article Pharmacological Approaches to Managing Violence and Aggression in Prison Populations: Clinical and Ethical Issues, written by Michael Weightman, Ranjit Kini, Robert Parker and Mrigendra Das, was originally published electronically in SpringerLink on 28 August 2020 without open access. After publication volume 80, issue 16, pages 1635-1647 with the author(s)' decision to opt for Open Choice the copyright of the article changed on 14 February 2022 to (C) The Author(s) 2022 and the article is licensed under a Creative Commons Attribution-NonCommercial 4.0 International License, which permits any non-commercial use, sharing, adaptation, distribution and reproduction in any medium or format, as long as you give appropriate credit to the original author(s) and the source, provide a link to the Creative Commons licence, and indicate if changes were made. The images or other third party material in this article are included in the article's Creative Commons licence, unless indicated otherwise in a credit line to the material. If material is not included in the article's Creative Commons licence and your intended use is not permitted by statutory regulation or exceeds the permitted use, you will need to obtain permission directly from the copyright holder. To view a copy of this licence, visit http://creativecommons. org/licenses/by-nc/4.0/.

The original article can be found online at https://doi.org/10.1007/ s40265-020-01372-2.

Mrigendra Das

mrigendra.das@nt.gov.au

1 Forensic Mental Health Team, Top End Mental Health Service, Tamarind Centre, 12 Ross Smith Avenue, Parap, Northern Territory 0820, Australia

2 Flinders University, Darwin, Northern Territory, Australia

3 University of New South Wales, Sydney, NSW, Australia

4 James Cook University, Townsville, Queensland, Australia
The original article has been corrected.

Open Access This article is licensed under a Creative Commons Attribution-NonCommercial 4.0 International License, which permits any non-commercial use, sharing, adaptation, distribution and reproduction in any medium or format, as long as you give appropriate credit to the original author(s) and the source, provide a link to the Creative Commons licence, and indicate if changes were made. The images or other third party material in this article are included in the article's Creative Commons licence, unless indicated otherwise in a credit line to the material. If material is not included in the article's Creative Commons licence and your intended use is not permitted by statutory regulation or exceeds the permitted use, you will need to obtain permission directly from the copyright holder. To view a copy of this licence, visit http://creativecommons.org/licenses/by-nc/4.0/. 